\title{
The dairy farming support system: Do the direct payments cause economic inefficiency?
}

\author{
Anna Guðrún Ragnarsdóttir, Birgir Pór Runólfsson and Ragnar \\ Arnason. ${ }^{1}$
}

\begin{abstract}
Economic distortions created by the dairy farming support system in Iceland are examined in this paper. Specifically, the impact of the direct payments component of this system is analyzed. The analysis lead to the conclusion that the form of direct payments that has been used is in many ways well-suited to improve dairy farmers' living standards without creating additional social costs in terms of resource misallocation. It follows that it would be socially wasteful, as well as economically detrimental to dairy farmers, to replace this system with an economically less efficient way of providing them with the same amount of financial support.
\end{abstract}

JEL classification: $H 2, H 21, Q 1, Q 18$

Keywords: Dairy quotas; subsidies in agriculture.

1 Anna Guðrún Ragnarsdóttir, project manager at the Institute of Economic Studies University of Iceland. Birgir Pór Runólfsson, docent, the Faculty of Economics, University of Iceland. E-mail: bthru@hi.is. Ragnar Arnason, professor, Faculty of Economics, University of Iceland. E-mail: ragnara@hi.is. 


\section{Introduction}

In Iceland, as in most developed countries, there is a long tradition of government interventions in the domestic agricultural market. These interventions take many forms including restricting trade across borders, the pricing of agricultural products and financial support to the farming industry. The history of state support for dairy farming in Iceland stretches back at least to the 1930s (Stefánsson, 1986; Stefánsson, 1998). Over time, both the form and extent of this support has been repeatedly altered, sometimes quite radically. In recent decades much of the support has consisted of a combination of a minimum price and various financial subsidies to farmers, as well as tariffs.

Since 1992, a major component of state support for dairy farming has been in the form of direct payments to farmers for production up to a certain upper limit. These payments are in addition to what dairy processors pay to the farmers. Our analysis here is focused on the system in the period 1992-2016, as will be further detailed and explained below. Under this system, the government, after consulting with the association of dairy farmers and association of dairies, annually sets the total volume of milk that will receive direct payments during the following calendar year. ${ }^{2}$ Individual farmers hold rights to these direct payments expressed as shares of the stipulated total volume entitled to direct payments, and receive direct payments according to their production up to their individual share. Production in excess of their individual share is permitted but does not receive direct payments. It is readily seen that this system, referred to in Iceland as the direct payment quota system ("greiðslumarkskerfið"), is essentially an individual quota system for production subsidies.

This paper is concerned with the economic implications of the direct payment quota system in dairy farming. Although, subsidies that do not alter (or distort) economic behaviour may not exist, it is intuitively obvious that different forms of supports may have differential impacts in this respect. The dairy support system in Iceland is based for the most part on four pillars: (i) tariffs to limit or prevent imports of dairy products, (ii) guaranteed minimum producer prices, (iii) the direct payment quota system, and iv) various other support payments. The primary question considered in this paper is whether the direct payment quota system causes economic inefficiency in dairy farming in addition to the inefficiency that tariffs and minimum prices may generate. ${ }^{3}$ A secondary question, also considered in the paper, is whether moving from the direct payment quota system to a system of direct payments for all production would increase or decrease the level of inefficiency that resulted from the dairy support system in place in 1992-2016. ${ }^{4}$

The paper is organized as follows. The key elements of the current dairy farming support system are described in the next section. In section 3, the essential components of this system are modelled and its economic implications examined. The policy implications of the work are discussed in section 4. Finally, in section 5, the main results of the paper are discussed.

2 A fuller description of this framwork is provided in secton 2 below.

3 We say additional, as it is well established that trade restrictions, such as tariffs and ban on imports, as well as guaranteed minimum producer prices generally cause inefficiencies. The question in this is paper whether the direct payments system adds to that inefficiency.

4 Regulations on the dairy support system were changed for 2017 (Regulation no. 1150/2016) with the aim of moving away from the direct payment quota system to a system of direct payments for all production (per litre subsidy). 


\section{The dairy support system: Basic description}

Until 1980 there were no official restrictions on the volume of milk production. Farmers, however, were guaranteed a certain government set minimum price for the milk they supplied to dairies. This led to production in excess of domestic demand which was exported with the help of state provided export subsidies (Kristófersson et al., 2007).

In 1980, in order to curtail the growth in export subsidies, a system to limit production (the so-called "búmarkskerfi") was adopted. According to this system, individual dairy farmers were to receive the full minimum price for production only up to a certain maximum volume which was set according to their average production 1976-8 (Stefánsson, 1998). Thus, this system was essentially an individual farm quota system for price supports, with only production within the farm quota being entitled to the full minimum price. Importantly, however, export subsidies for excess production were retained. This system led to a certain reduction in dairy production but not sufficiently to allow the payment of the full minimum price for all production (Stefánsson, 1998; Kristófersson et al., 2007). In response to the continuing overproduction, the system was modified in 1985. The overall production quota (referred to as "fullvirðisréttur") was divided between 25 regions and individual farm quotas revised in accordance with their actual production in 1982-5. This further reduced overproduction (Kristófersson et al., 2007; Ásmundsdóttir,2012).

A major overhaul of the dairy support system took place in 1992 (Act no. 99/1993; Kristófersson et al., 2007). ${ }^{5}$ Most importantly, subsidies to dairies and export subsidies were abolished. In their place direct payments from the state to farmers for production up to a certain pre-decided volume or quota (referred to as "greiðslumark") were introduced. The minimum price system was retained. So, the direct payments were on top of the minimum price received by the farmers from the dairies. The individual farm quotas, designated as percentages of the total production volume entitled to direct payments ("heildargreiðslumark"), were allocated in a way similar to what had applied previously. Importantly, these quotas were made explicitly transferable albeit with certain restrictions. As before, these quotas were not limits on production. However, for production in excess of the quota, farmers only received the price the dairies were willing to pay.

5 The parliament passed legislation to overhaul the agricultural support system in 1992. The Act on the Production, Pricing and Sale of Agricultural Products (Act No. 46/1985), which applies both to sheep farming and dairy production, was changed (Acts no. 5/1992 and no. 112/1992) and then re-written and re-issued as Act no. 99/1993. The Act lays down that a binding agreement on dairy production must be made with the Farmers Association. Within this framework, policies are determined by renewable multi-year agreements between the government and the Farmer's Association, which provides the general framework for support and production control in covered sectors. One of these agreements covers the dairy sector, the Agreement on Dairy Production, and expired in 2016. That agreement, and previous ones since 1991, are the basis of our analysis here. A new agreement has since been negotiated and enacted for the period 2017-2026. The new agreement brought changes to the direct payments system with an aim to abolish the quota system and replace it with a system of production subsidies (see Act no. 102/2016 and the 2016 agreement on dairy production). Hence, our secondary question posed in the introduction. 


\subsection{The essentials of the system in 1992-2016}

In addition to import restrictions and tariffs, ${ }^{6}$ the dairy support system consists of the following three main components:

1. A minimum price per litre of milk supplied to and payable by dairies. This price is set by the Agricultural Pricing Committee ("Verðlagsnefnd búvara").

2. Supplementary direct payments ("beingreiðslur") from the state to farmers for milk delivered to dairies up to a predetermined total volume ("heildargreiðslumark").

The key elements of this system are:

- The Government (Parliament) decides on the amount of total direct payments for each calendar year. In what follows, we refer to this amount as $S .{ }^{7}$

- The Government (Ministry of Agriculture), having received proposals by the association of dairy processors and the association of dairy farmers (Landssamband kúabænda), decides on the total volume of milk production entitled to direct payments ("heildargreiðslumark") per calendar year. We refer to this volume as the total direct payment quota and denote it by $Q$.

- The potential direct payment to farmers per litre of milk delivered to dairies and entitled to direct payments is thus defined as $s=S / Q$.

- The actual payment received by individual farmers depends on their level of production according to a fairly complicated payment formula. ${ }^{8}$

- The total direct payment quota, $Q$, is shared amongst individual dairy farms with farm $i$ holding the fraction $a(i)$.

- Once the total direct payment quota has been set, the individual direct payment quotas are determined as $q(i)=a(i) \cdot Q .{ }^{9}$

- The direct payment quota shares, $a(i) \mathrm{s}$ are transferable with some restrictions.

3. Various other supports such as payments per head of cattle, supports for breeding programs (genetic improvements), land improvement supports, supports for construction and improvement of stables and other facilities.

Of these categories of support, only the second and third represent outlays by the government; the first is paid for by consumers in the form of a higher price for milk

6 For a short summary on the import tariffs and other import restrictions, see the Institute of Economics Studies report on the dairy industry (Hagfræðistofnun 2015).

7 Prior to the government decision, negotiations between the Ministry of Agriculture and the Farmers' Associations take place (see also footnote 5 above). The game-theoretic aspects of these negotiations are interesting but irrelevant for and outside the scope of this paper.

8 According to the regulations for the 2016 calendar year (no. 1220/2015), the direct payment to any given dairy farmer is divided into three categories, A, B and C. Payment A amounting to $40 \%$ of the payment per litre (i.e. s) becomes fully payable if the farmer produces $80 \%$ or more of his individual quota during the year. For less production, the A payment is proportional to the level of production. Payment B amounting to $35 \%$ of $s$ depends directly on the level of production. Payment C, amounting to $25 \%$ of $s$ is only paid in full for the volume the farmer produces at least $1 / 12$ of his annual quota during each of the last 7 months of the year. The direct payment schedule is explained and considered in further detail in the Appendix.

9 But see also previous footnote. 
products than would otherwise be the case. In 2016, the government expenditures on support categories 2 and 3 were 6.6 billion $\mathrm{kr}$. of which direct payments amounted to about 5.5 billion kr. or 83\% (Ríkisreikningur, 2016).

It should be noted that the minimum price payable by dairies is sustained by tariffs, import restrictions and strict quality controls on the importation of dairy products including the main ones (fresh milk, cream and butter). Without these import barriers, it would not be possible for the dairy processors to pay the minimum price for the milk supplied to them by farmers. Thus, the import restrictions are an integral part of the overall dairy support system. Without it the minimum price regime would likely collapse.

It is important to realize that the dairy support system in effect does not impose a restriction on the volume produced by individual farmers. They are allowed to produce as much as they want. ${ }^{10}$ However, they will not receive direct payments for production in excess of their direct payment quota and while the dairies have in practice often paid the minimum price for milk supplied in excess of the direct payment quota, they are not required to do so.

\subsection{Quantitative description of the 1992-2016 system}

Table 1 summarizes key quantitative information about the operation of the direct payments system from 2005 onward. The second column of the table shows the total volume of milk production entitled to direct payments, i.e. the direct payment quota, $Q .{ }^{11}$ Apparently, the direct payment quota is supposed to reflect expected total domestic consumption of milk products and, therefore, is determined by previous consumption as well as estimated change in consumption (Act no. 99/1993, article 52). Hence the increasing trend over time.

The third column in table 1 shows the total amount of direct payments, $S$, evaluated at the 2016 price level. Note that this amount (total direct payments) declined substantially in real terms since 2005 or by some $23 \%$.

The fourth column in table 1, obtained as the ratio of the third to the second columns, shows the direct payments per litre of production. As is readily seen, the direct payments per litre have fallen drastically in real terms since 2005 or by almost 2/5.

10 The regulations issued by the Ministry (based on Act 99/1993) obligate the dairy producers and processors to export all products in excess of the total volume of the support quota. But the same regulations also provide for exemptions from those obligations. See article 3 in Regulation no. $1220 / 2015$.

11 Until the end of 2010 the direct payment quota was set for the so-called "price years" ("verðlagsár") which were defined from the $1^{\text {st }}$ of September to the 31 $1^{\text {st }}$ of August. From 2011, this was switched to the calendar year. In table 1 , for conformity over time, the total payment quota per calendar year before 2011 has been approximated by weighted average by months (Institute of Economic Studies, 2015). 
Table 1. Total dairy support system: key information

\begin{tabular}{cccccc}
\hline & $\begin{array}{c}\text { Direct payment } \\
\text { quota } \\
\text { (million litres) }\end{array}$ & $\begin{array}{c}\text { Total direct } \\
\text { payments } \\
\text { (billion ISK) }\end{array}$ & $\begin{array}{c}\text { Direct pay- } \\
\text { ments per litre } \\
\text { (ISK/litre) }\end{array}$ & $\begin{array}{c}\text { Minimum ex } \\
\text { farm price } \\
\text { (ISK/litre) }\end{array}$ & $\begin{array}{c}\text { Total } \\
\text { revenue } \\
\text { (ISK/litre) }\end{array}$ \\
\hline 2005 & 107.7 & 7.2 & 66.7 & 76.1 & 142.8 \\
\hline 2006 & 112.7 & 7.0 & 62.8 & 75.6 & 138.4 \\
\hline 2007 & 116.3 & 6.6 & 57.2 & 77.4 & 134.6 \\
\hline 2008 & 117.7 & 6.2 & 53.4 & 88.2 & 141.6 \\
\hline 2009 & 118.1 & 5.7 & 47.5 & 87.6 & 135.1 \\
\hline 2010 & 116.3 & 5.4 & 46.8 & 81.5 & 128.2 \\
\hline 2011 & 116.0 & 5.4 & 46.7 & 83.8 & 130.6 \\
\hline 2012 & 114.0 & 5.4 & 47.2 & 82.8 & 130.0 \\
\hline 2013 & 116.0 & 5.4 & 46.2 & 81.8 & 127.9 \\
\hline 2014 & 125.0 & 5.5 & 43.8 & 83.0 & 126.8 \\
\hline 2015 & 140.0 & 5.5 & 39.5 & 83.5 & 123.1 \\
\hline 2016 & 136.0 & 5.5 & 40.6 & 85.3 & 125.9 \\
\hline
\end{tabular}

Sources: Regulations on "greiðslumark mjólkur á lögbýlum og greiðslur til bænda", Hagfræðistofun (2015), Ministry of Industries and Innovation, Statistics Iceland and authors' calculations. Notes: All monetary values at 2016 price level. This is calculated as the nominal price divided by the consumer price index without housing set at unity in 2016.

The fifth column in table 1 shows the minimum price payable by dairies to farmers for a litre of first-rate milk produced within the individual direct payment quota. As already stated, this minimum price is determined each year by the Agricultural Pricing Committee ("Verðlagsnefnd búvara"). ${ }^{12}$ As can be seen in table 1, the minimum price, measured in 2016 real terms, increased considerably until 2008 but has been relatively constant since then.

A farmer's total revenue per litre of milk produced is the sum of the direct payment per litre and the minimum price. This is shown in the last column in table 1. It shows that the total revenue (calculated price) per litre has declined since 2005 by almost $12 \% .{ }^{13}$

\subsection{Direct payment quotas and milk production}

As pointed out above, the individual direct payment quota is not a production quota. It does not constrain the farmer to produce only the volume that the payment quota stipulates. Rather, the payment quota simply defines a right to a government subsidy per litre of production up to the quota limit (further details on the subsidy price per litre are in the Appenix). In fact, every year dairy farmers have produced milk considerably in excess of the direct payment quota (see table 2 ). ${ }^{14}$

12 This minimum price is supposed to ensure that dairy farmers' income is similar to that of comparable professions. As such it incorporates information on production costs (Act No. 99/1993, Article 8) as well as the expected direct payments.

13 The total amount of the direct payments has declined, in real terms (2016 price level), by $25 \%$, and total government payments to the dairy sector has declined, in real terms, by $11 \%$ in this same period, 2003-2016.

14 Milk production has been in excess of the total payment quota volume every year since the late 1990s. 
Table 2. Production of excess milk

\begin{tabular}{|c|c|c|c|c|}
\hline & $\begin{array}{l}\text { (1) } \\
\text { Direct payment quota } \\
\text { (million litres) }\end{array}$ & $\begin{array}{l}\text { (2) } \\
\text { Total production } \\
\text { (million litres) }\end{array}$ & $\begin{array}{c}\text { (3) } \\
\text { Excess milk } \\
\text { (million litres) }\end{array}$ & $\begin{array}{c}(4) \\
(3) /(1)\end{array}$ \\
\hline 2005 & 107.7 & 109.4 & 1.8 & $1.7 \%$ \\
\hline 2006 & 112.7 & 117.1 & 6.1 & $5.5 \%$ \\
\hline 2007 & 116.3 & 124.8 & 8.8 & $7.6 \%$ \\
\hline 2008 & 117.7 & 126.1 & 9.1 & $7.7 \%$ \\
\hline 2009 & 118.1 & 125.6 & 6.6 & $5.5 \%$ \\
\hline 2010 & 116.3 & 123.2 & 7.2 & $6.2 \%$ \\
\hline 2011 & 116.0 & 124.8 & 8.8 & $7.6 \%$ \\
\hline 2012 & 114.0 & 125.2 & 10.7 & $9.3 \%$ \\
\hline 2013 & 116.0 & 122.9 & 6.9 & $6.0 \%$ \\
\hline 2014 & 125.0 & 133.6 & 8.6 & $6.9 \%$ \\
\hline 2015 & 140.0 & 146.1 & 6.1 & $4.3 \%$ \\
\hline 2016 & 136.0 & 150.4 & 14.4 & $10.6 \%$ \\
\hline
\end{tabular}

Sources: Regulations on "greiðslumark mjólkur á lögbýlum og greiðslur til bænda", Auðhumla, SAM ("Samband afurðastöðva í mjólkuriðnaði") yearly reports.

Milk production in excess of direct payment quota, referred to as excess milk ("umframmjólk"), may be sold to dairies but it is not subject to the minimum price stipulated by the Agricultural Pricing Committee. ${ }^{15}$ The dairies are free to pay a different price for the excess milk and the farmer does not receive any direct payments for excess milk (but see Appendix further on this). The price that dairies have paid for excess milk has been highly dependent on the domestic demand for milk products relative to the production. In years of high demand relative to production, the dairies have proved willing to pay at least the minimum price. When domestic demand has been low relative to production and the dairies have been forced to produce low priced products such as milk powder for export, they have offered considerably lower price for the excess milk (Institute of Economic Studies, 2015). ${ }^{16}$

15 This committee not only sets the minimum price (for various grades of milk) that dairies have to pay farmers for their milk. The dairy production sector is bound by price controls on all standard products, such as whole milk, skimmed milk, cream, plain butter, hard cheese, plain skyr, and milk powder. The committe therefore sets the maximum (ceiling) wholesale level prices for these products (it in effect attempts to calculate a proper margin that the dairies need to recover production costs on top of the minimum prices paid to milk farmers). Other non-standard dairy products, such as varieties of cheeses, buttermilk, yogurt, etc. are not subject to price controls. Also, there is freedom of pricing at the retail level. The Institute of Economic Studies (2014:46-47) report shows that wholesale prices for those dairy products subject to price ceilings have declined in real terms (price level 2013) by 1\%-18\% in 2003-2013; cream price declined most and skimmed-milk powder the least. They also show that retail prices for these products have increased less than the general consumer price index in the same period. This suggests that slowly decreasing government support to the dairy industry is increasing consumer surplus.

16 This market price for excess milk was about 50-70\% of the minimum price in 2008-2013, but in 20132016 it increased to $100 \%$. It was approximately $75 \%$ of the minimum price from July 2016. For information on price of unprocessed milk, see Audhumla.is. 
Table 2 shows the volume and percentage of excess milk produced by dairy farmers from 2005. The table shows that in spite of the marginal revenue for excess milk being substantially lower than marginal revenue for milk produced within the direct payment quota, farmers have elected to produce a significant amount of excess milk every year. On average since 2005, the volume of excess milk produced has been $6.6 \%$ of the direct payment quotas. Most of the years, the excess milk production has been above $5 \% .{ }^{17}$ In only one year, 2005 , has it been below $2 \% .{ }^{18}$

Farmers, of course, produce excess milk because they deem it profitable. In the short run, the marginal cost of producing milk may be low because the necessary investment in cows and facilities is already there. However, a persistent and substantial production of excess milk is strong evidence that at least some farmers and therefore the industry as a whole can produce milk at a (marginal) cost below the minimum price.

\subsection{Transferability of direct payment quotas}

The direct payment quotas held by individual farmers are transferable (Act No. 99/1993). ${ }^{19}$ During the early years of the direct payments system (in the 1990s), these transfers were for the most part unrestricted. However, subsequently, it was apparently felt necessary to impose restrictions on how these trades could proceed. According to regulations in 2010-2016, transfers of direct payment quotas took place under the auspices of MAST (the Icelandic Food and Veterinary Authority). MAST invited written bids and offers that were opened on specific market days (three times a year). On the basis of the bids and offers MAST worked out supply and demand schedules and calculated the so-called equilibrium price ("jafnvægisverð"). All lower bids and higher offers were then rejected and the remaining bids and offers became binding contracts.

From 2011 the annual volume of trades was generally between one and two million litres or above $1 \%$ of the total volume of outstanding direct payment quotas (Figure 1 ). This suggests considerable rearrangement of the milk production between farms under the direct payment system, a finding consistent with the reduction in the number of active dairy farms (see section 2.5 below) ${ }^{20}$

17 In the period 2001-2012 about 10\%-15\% of the volume of milk were exported (in the form of dairy products), but then fell substanstially in 2013-2016, averaging only about $1 \%$ in this period (see SAM, yearly report for 2016, p. 25).

18 The reasons for this low proportion of excess milk in 2005 is at least partly explained by two factors: First, there was a large increase in the direct payment quota from 106 million litres in 2004/2005 to 111 million litres in 2005/2006, an increase of 4.7\%. This, according to the new Agreement on Dairly Production in 2004, also meant a drop in direct payments per litre. Second, unfavorable weather in the spring and summer of 2005 made dairy farming unusually difficult that year (see Árskýrsla SAM 2005).

19 With the changes in regulations for 2017 (Regulation no. 1150/2016) the quotas are no longer freely transferable. Farmers wanting to sell now only have the option of "selling" to the government at a pre-announced government price (well below the market price in previous auctions in 2016) and farmers wanting to buy can apply/bid for quota (which will be met according to somewhat complicated allocation rules that stipulate eligibility).

20 In fact trade in dairly quotas has on average been about $3 \%$ of the production volume each year since 1992 (see Hagtölur Landbúnaðarins 2010, at bondi.is, MAST at mast.is, Rannís 2001 and Stöðumat og stefnumótun i mjólkurframleiðslu, skýrsla til landbúnaðarráðherra, febrúar 2004, at atvinnuvegaraduneyti.is). In the report Stöðumat og stefnumótun í mjólkurframleiðslu (2004) trades in quotas in the period 1998-2003 are analyzed specifically. Trades in quotas (where quotas were 


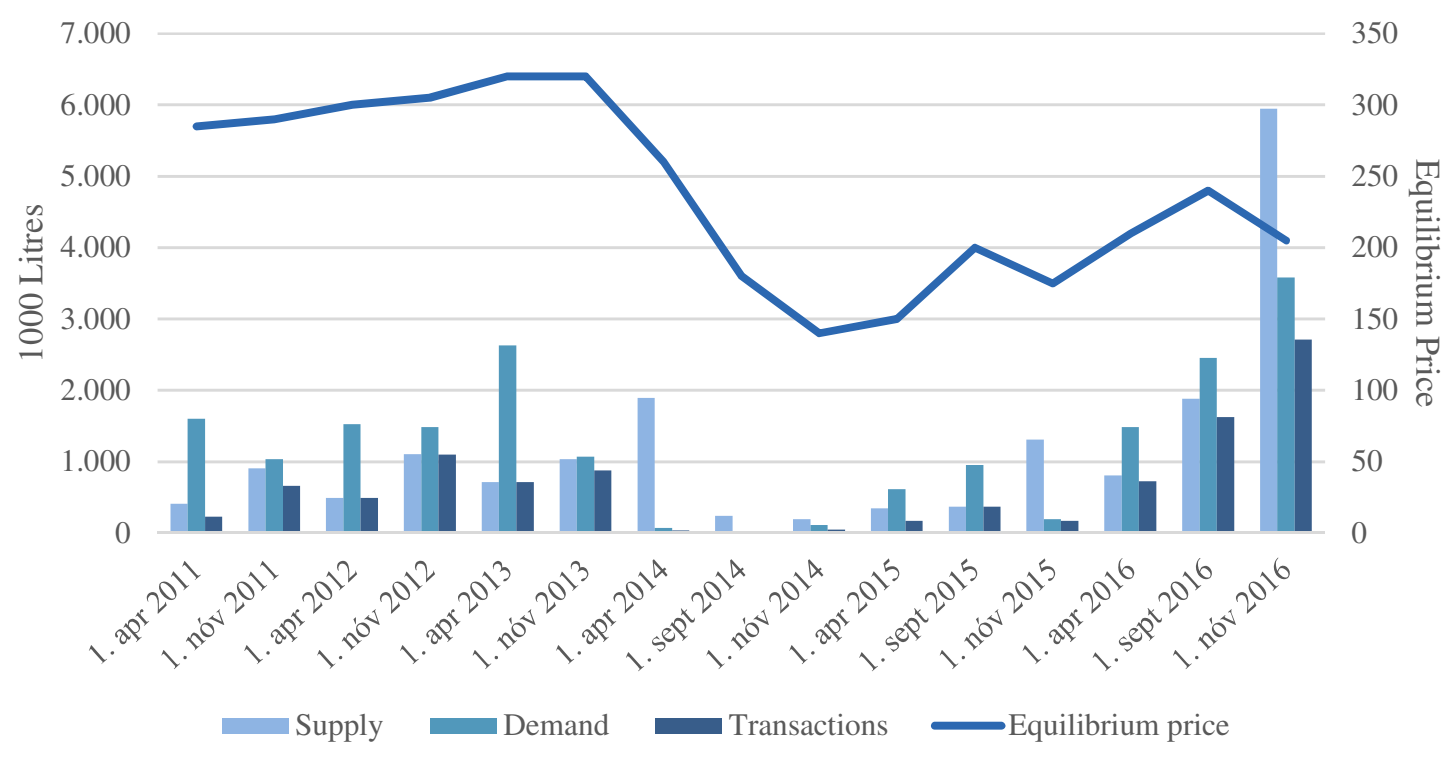

Figure 1. Direct payment quota markets and trades

Source: MAST.

Figure 1 summarizes key information about the market for direct payment quotas between 2010 and 2016. The figure shows considerable market activity until 2014. The total amount of supply (offers to sell) and demand (bids to buy) is very considerable with the volume of actual trades naturally being substantially lower.

As shown in figure 1, there was a severe drop in market activity and trades between 2014 and 2015. The reasons for this trough, while interesting, are outside the scope of this study. However, there are indications that uncertainty about the future of the direct payments system in connection with the general review of the overall dairly farming support system which got underway in 2014 may have played a major role in this. This hypothesis is lent certain quantitative support by the fact that the supply (offers to sell) of direct payment quotas during the first market period in 2014 was very high while the demand (bids to buy) was almost nonexistent. ${ }^{21}$

The direct payment quota market recovered in 2015 and especially 2016, apparently partly because of less uncertainty about the future of the system. ${ }^{22}$ In addition, it should be noted that market activity in the September and November 2016 may have been distorted upward by the

transferred between farms) were on average $4.7 \%$ of total volume of production each year and additionally another $4 \%$ were transferred on average each year through ownership changes of farms. Of these ownership changes, about a third were between unrelated parties while over $60 \%$ were based on next generation assuming ownership or incorporating the farm business. Based on this information, in addition to that mentioned above, we could infer that no less than $4 \%$ of quotas have changed ownership on average each year in 1992-2016. But, of course, some of this quota has been traded more than once in the period, so we should not assume that all or nearly all the quota has changed hands, although the number of dairy farms has decreased in this period from 1456 to 596, or by almost $3 / 5$.

21 The large increase in the volume of quota in 2013-2015, some $20 \%$ increase, may also have affected the lower trade in quotas, as well as the decision by dairies to pay full minimum price for excess milk from October 2013.

22 Expectations formed on news from the discussions between the farmers association and the government that the quota system would be retained in some form at least to 2020 . 
previous announcement of a provisional halt to direct payment quota trading from 2017 onward.

From 2010 to 2014, the equilibrium price for direct payment quotas was fairly constant at close to $300 \mathrm{kr}$./litre (at current price levels). However, it dropped considerably in 2014 and was around 200 to $250 \mathrm{kr}$./litre in 2015 and 2016. It may be noted that these direct payment quota prices (of five to seven times the direct payments) suggest either inordinately high discount rates of between 14 and $20 \%$ or the expectation that the system of direct payments will end in the near future (next 4 to 8 years) or both.

\subsection{Increased productivity}

There is considerable evidence of increased productivity in dairy production under the direct payments system at least since $2005 .{ }^{23}$ First, the number of farms has fallen and the average production per farm has increased substantially (see figure 2).

This suggests that technically available returns to scale in dairy production at the farm level are being exploited to a greater extent than before. Second, the total real price per unit of milk production received by the farmers (see table 1 and figure 3) has declined considerably since 2005 while at the same time, dairy farmers' net income has, if anything, improved. This also suggests improvement in productivity.

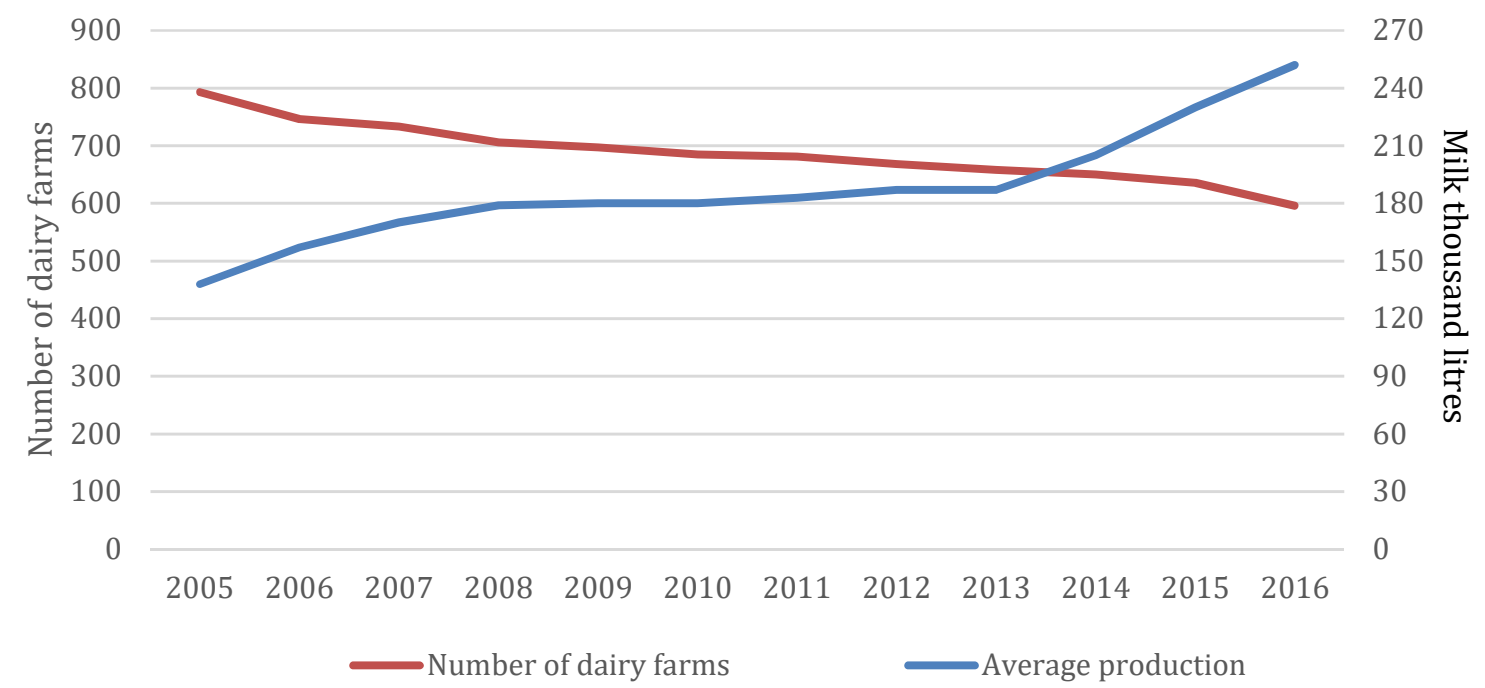

Figure 2. The number of dairy farms and their average production

Sources: Regulations on "greiðslumark mjólkur á lögbýlum og greiðslur til bænda", Auðhumla, SAM ("Samband afurðastöðvar í mjólkuriðnaði") yearly reports.

This suggests that technically available returns to scale in dairy production at the farm level are being exploited to a greater extent than before. Second, the total real price per unit of milk production received by the farmers (see table 1 and figure 3) has declined considerably since 2005 while at the same time, dairy farmers' net income has, if anything, improved. This also suggests improvement in productivity.

23 Actually, available production statistics (Auðhumla og ársskýrslur SAM) indicate a considerable growth in production per farm since 1978. This growth, however, became much more rapid from 1993 onwards as the system of direct payment was adopted. 


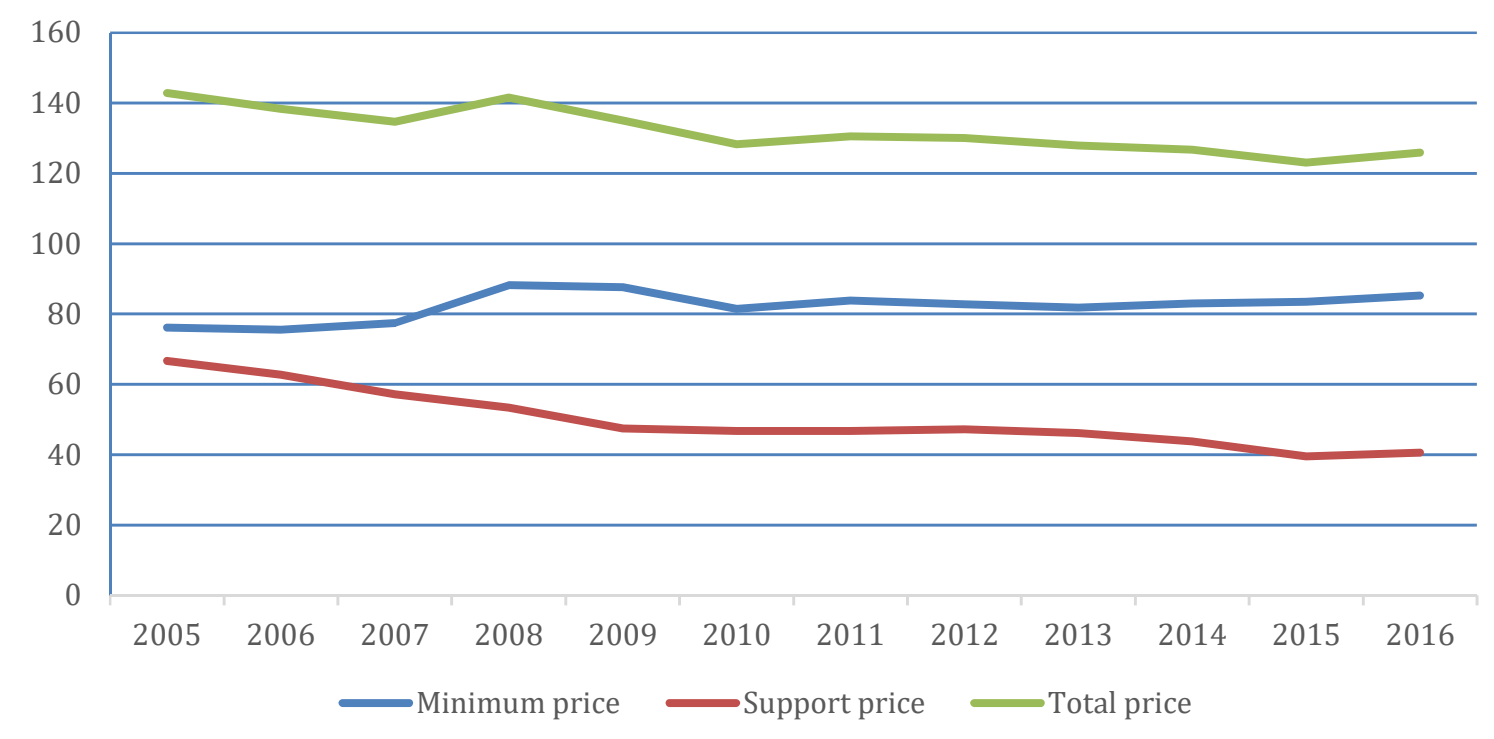

Figure 3. Real price per litre of production received by dairy farmers

Sources: Regulations on "greiðslumark mjólkur á lögbýlum og greiðslur til bænda", Auðhumla, SAM ("Samband afurðastöðvar í mjólkuriðnaði") yearly reports.

As explained above, the total price received by dairy farmers for their production consists of the minimum price paid to them by the dairies and the direct payments received from the state. The evolution of these prices in real terms (2016 price level), is illustrated in figure 3. As is evident from the figure, the total price has declined considerably or by $12 \%$ since 2005 . Since, apparently, dairy farmers' net income has not declined during this period, this decline in the real price is indicative of at least the commensurate annual growth in total factor productivity of dairy farming since 2005.

Interestingly, the fall in the real price received by dairy farmers is explained solely by the fall in the real value of the direct payments per litre of production. These payments have fallen by almost 2/5 since 2005 (for details see table 1), while the real value of the minimum price has actually increased slightly.

\section{Analysis}

In this section we attempt to explain the impact of two of the main strands of the milk production support system, namely the minimum price and the direct payments, on the level of milk production and economic efficiency. In accordance with standard economic practice, we assume that all prices, except the price of unprocessed milk, are true, i.e. accurately measure marginal social benefits and costs.

We further take it for granted that there exists a domestic demand function for unprocessed milk with the usual properties (positive for some positive price, continuous, and downward sloping). We write the inverse of this function as:

$$
D(q, \mathbf{z}), D_{q}<0
$$


where $q$ is the quantity of unprocessed milk. The vector $z$ represents other variables that may affect the demand and $D_{q}$ denotes the first derivative of the demand function (where it exits) with respect to the quantity of milk. Needless to say, this demand function is derived from the final demand for milk products. In this paper, however, the downstream stages of the value chain for milk products are not of concern. ${ }^{24}$

Similarly, we take it that there exists an import supply function for unprocessed milk. For our purposes it is most convenient to define this supply as the same quality unprocessed milk delivered at the same locations and in the same containers as domestic milk. Therefore, although this supply price, $p_{w}$, may be taken to be closely related to the world supply price of unprocessed milk, it would generally be somewhat higher. We write this supply price as:

$$
p_{w}=S_{w}(q)
$$

Relative to the possible size of the Icelandic demand, it is safe to assume that the slope of this function is zero, i.e. the import supply is infinitely elastic implying a constant supply price $p_{w}$. Importantly, this import price represents the price at which Icelandic society can obtain unprocessed milk from abroad. It thus reflects the true (or shadow) price of unprocessed milk in Iceland.

The domestic supply of unprocessed milk comes from several hundred dairy farmers. Let the number of these farmers be $I$. Their individual production costs may presumably be represented by the increasing cost functions:

$$
C(q(i), x ; i), i=1,2, \ldots I \text {, }
$$

where $q(i)$ is the supply of farmer $i$, and $x$ a vector of other variables affecting production costs including technology, farm attributes and so on. In what follows, for notational simplicity, reference to the vector $x$ will generally be suppressed. For convenience we assume that these cost functions are twice continuously differentiable.

Assuming, quite reasonably, that all of these dairy farmers are price takers, it is wellknown that their individual supply functions are the upward sloping part of their marginal cost functions (see e.g. Varian 1984). ${ }^{25}$ In other words:

$$
p=C_{q(i)}(q(i) ; i), i=1,2, \ldots I,
$$

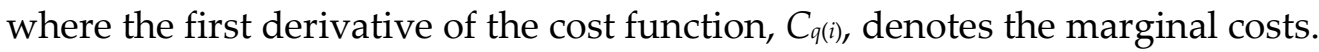

24 In fact the demand curve (function) does not play a role or affect our analysis below. It is only to illustrate the traditionl approach to explaining the welfare losses from restrictions on trade and price formation that we use it here in this section of the paper. In section 3,1 and after, the minimum price + support price are the relevant demand. But the supply curve (function) has a role and affects the analysis.

25 Production ranges over which the cost function is nonconvex (e.g. increasing returns to scale) are irrelevant here because price takers never find it optimal to produce there (see e.g. Varian 1984). 

13

The aggregate (total) domestic supply of unprocessed milk is simply the horizontal sum of the (upward sloping part) of the individual marginal cost functions (Hicks 1946, see also Varian 1984):

$$
q=\sum^{I} q(i)=\sum^{I} C_{q(i)}^{-1}(p ; i) \equiv F(p, I)
$$

where $q$ denotes the total supply and the functions $C_{q(i)}^{-1}(p ; i)$ are the inverse functions of the upward sloping parts of the individuao marginal cost functions. Note that the aggregate supply function $F(.,$.$) depends, among other things, on the number of farms producing, which$ we have referred to as $I$.

Inverting the last function in (5) provides the domestic supply function as:

$$
p=S(q, I), S_{q}>0
$$

This must be positively sloping because the individual marginal cost functions are. ${ }^{26}$

It seems helpful to illustrate the system defined by equations (1), (2) and (4) by the usual quantity-price diagram for the milk market. This is done in figure 4 . In this figure, the domestic demand is labelled $D(q)$, domestic supply $S(q)$ and the import supply function by the import price, $p_{w}$.

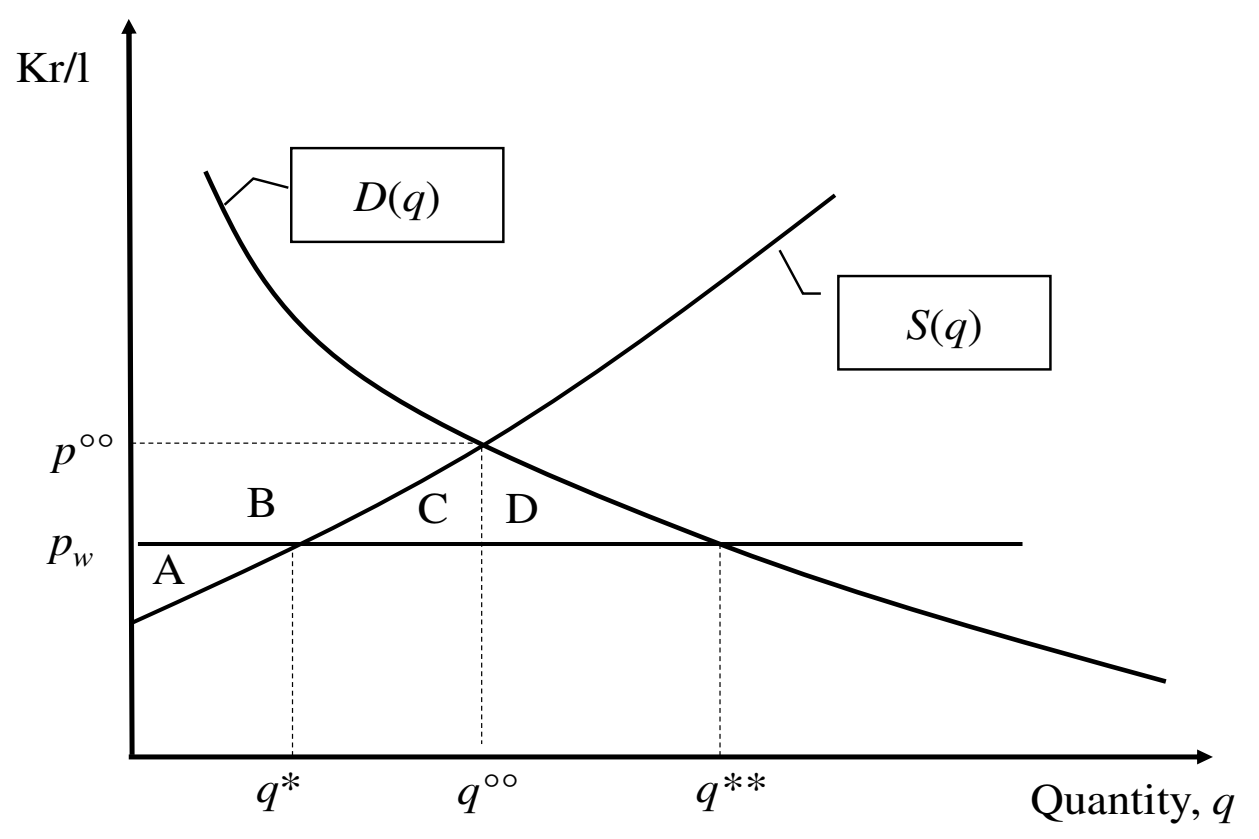

Figure 4. The domestic milk market: basic supply and demand

26 It is useful to note, however, that because of the horizontal summation the aggregate supply function is generally flatter and usually much flatter than the individual supply functions. 
Now, there are indications that a part of the domestic milk production can be supplied at cost at or below the import price, $p_{w}{ }^{27}$ Consequently the domestic supply curve is drawn accordingly. It should be mentioned, however, that, for the analysis of this paper, it is of no consequence whether domestic industry can actually supply a positive quantity at or below the import price.

As the functions in figure 4 are drawn, under free trade, market equilibrium would be at the import price, $p_{w}$, and quantity $q^{* *}$ of which the domestic supply would be $q^{*}$. Total social benefits of this market equilibrium would be approximately the consumer surplus measured by the integral underneath the demand function, $\int_{0}^{q^{* *}} D(q)-p_{w} d q$, plus the producer surplus indicated by the area $\mathrm{A}$ in the diagram (Varian 1984).$^{28}$ Note that if the domestic supply price always exceeds the world import price, the socially optimal domestic production, $q^{*}$, would be zero and therefore also the producer surplus A.

At this point it is crucial to realize that any domestic production of milk in excess of $q^{*}$ is economically inefficient. The reason is that the cost of producing more than $q^{*}$ is higher than the price for which the product is available from abroad. This means that the domestic economic resources used to produce above $q^{*}$ would be better used in other activities. Moreover, the degree of inefficiency increases with the level of production beyond $q^{*}$. We state this formally as result 1

\section{Result 1}

Any domestic production above $q^{*}$ is economically inefficient. The degree of inefficiency increases with the distance from $q^{*}$.

For later use it is convenient to define the social loss of producing milk in excess of $q^{*}$. From a social perspective, the producer surplus of any production, $q$, is

$$
B(q)=\int_{0}^{q} p_{w}-S(\tilde{q}) d \tilde{q}
$$

This benefit function has a maximum at the socially optimal production level $q^{*}$. At $q^{*}$ the producer surplus is $B\left(q^{*}\right)$ which equals the area $A$ in figure 4 . Thus the social loss of producing $q$ is simply:

$$
L(q, q *)=B(q *)-B(q)
$$

It is easy to see that this social loss function has a minimum of zero at $q=q^{*}$, is positive for any other levels of production and at least weakly convex. An example of its shape is illustrated in figure 5 .

27 For instance some Icelandic dairy farms employing the state-of-the-art technology (robotic milking in a free-stall cow houses) and, producing close to million litres per year, are close to the efficient European diary farm size. Since farming land is inexpensive in Iceland, there seems no reason to believe that production costs in these farms are significantly higher than abroad.

28 For a useful discussion about the accuracy of the consumer surplus measures, see Willig (1976). 


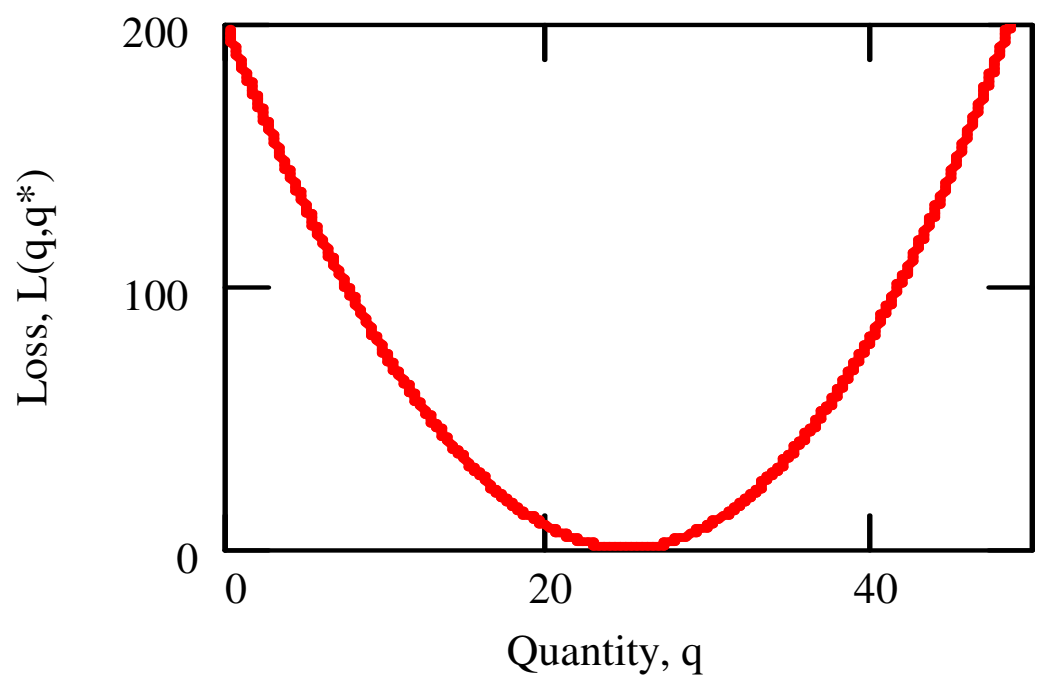

Figure 5. The social loss function: an example

To induce domestic producers to produce above $q^{*}$ it is necessary to offer them a price above the import price, $p_{w}$. This will lead to a social loss in production approximately measured by the social loss function (8). If, in addition, consumers are asked to pay the higher price, there will be a loss in consumer surplus as well. As an example, imagine in figure 4 that import of unprocessed milk is not allowed. In that case, all milk would be domestically produced and the market equilibrium would occur at $\left(q^{\circ \circ}, p^{\circ \circ}\right)$. At this point there would be a total social loss amounting to the area $\mathrm{C}+\mathrm{D}$. The total social loss would not be equally distributed. Producers of milk who enjoy the higher price, $p^{\circ}$, would gain $\mathrm{B}$ while the demanders of unprocessed milk, who have to pay the higher price, $p^{\circ \circ}$, would lose $\mathrm{B}+\mathrm{C}+\mathrm{D} .{ }^{29}$

\subsection{The milk production support system}

As described in section 2, there is an extensive support system for primary milk production in Iceland. Most importantly, there are substantial barriers (import restrictions, tariffs and quality controls) on the import of unprocessed milk and several final milk products. In addition to this, domestic producers are supported primarily in three ways:

1. Minimum price for unprocessed milk supplied to dairies.

2. Direct payments from the state for production up to a certain volume ("heildargreiðslumark").

3. Various other supports.

Here we only consider the first two. The third consists of a number of production and investment supports (see section 2.1) which together amount to a small fraction of the other

29 Although the restriction of international trade in milk and related products is not the topic of analysis here, it may be of interest to the reader that in Hagfræðistofnun (2015) the production inefficiency resulting from trade restriction in Iceland is estimated to be of the size of 0.5-3.0 billion kr. pr. year. 
two. ${ }^{30}$

The minimum price is easily modelled as simply $p_{\text {min }}$ which to be effective must be higher than the import price, $p_{w}$.

The direct payment from the state to holders of direct payment quotas is a bit more involved. The direct payment per litre of unprocessed milk subject to direct payments may be defined as: ${ }^{31}$

$$
s=\frac{S}{Q}
$$

Where $S$ is the total amount allocated to direct payments and $Q$ is the direct payment quota, i.e. the total volume of milk entitled to direct payments. As explained in section 2, the total direct payment is determined annually by the state budget. The direct payment quota, however, is determined subsequently by regulations issued by the Ministry of Agriculture, as mentioned above.

Let us now try to incorporate these two main components of the dairy support system into the basic unprocessed milk market situation illustrated in figure 4 . This is attempted in figure 6 .

Under the dairy support system, the price per litre of production received by the dairy farmers (their effective demand function) is the minimum price plus the direct payments from the state.

The minimum price, $p_{\min }$, is drawn as a horizontal line in figure 6. Dairy processors may of course offer a higher price than $p_{\min }$ or a lower minum price for quantity above the direct payment quota, indicated by $Q^{\prime}$ in figure 6 . If so, the minimum price will not be a horizontal line. This, however, as is easy to verify, will not materially affect the ensuing analysis.

The direct payments depend on the total funds allocated to direct payments, $S$, and the total direct payment quota, $Q$, as defined in equation (9). These direct payments (added to the minimum price) are drawn as the dashed curve in figure 6 . The curve is dashed because it illustrates the total price to holders of direct payment quotas for various levels of total direct payment quota, $Q$. Only when $Q$ has been selected will the amount of direct payments per litre of milk be determined.

Let us now assume that the total direct payment quota has been set at $Q^{\prime}$ in figure 6 resulting in direct payments per litre of $s=S / Q^{\prime}$. In that case, dairy farmers will receive a price per litre of milk amounting to $s+p_{\min }$ for production up to volume $Q^{\prime}$. For production above $Q^{\prime}$, however, dairy farmers only receive the minimum price, $p_{\text {min. }}$ Thus, in effect, dairy farmers are faced with a one-step demand function indicated by the bold price lines in figure 6 . The price is constant at $s+p_{\min }$ up to production volume $Q^{\prime}$. At $Q^{\prime}$ there is a discontinuous fall in the price to $p_{\text {min. }}{ }^{32}$

30 In 2016, these other supports amounted to only about $17 \%$ of the total state supports (Ríkisreikningur 2016). The state supports, however, do not include the minimum price supports which consumers pay.

31 To actually receive the full direct payments per litre produced, farmers have to meet certain other payment conditions (see the Appendix).

32 Due to the direct payment conditions (see the Appendix) the actual direct payments for production below $Q^{\prime}$ may possibly deviate from $s$. This, however, does not materially affect the anlysis; only the shape of the $s^{+} p_{\min }$ schedule below $Q^{\prime}$ is affected. Moreover, this part of the price schedule is not 


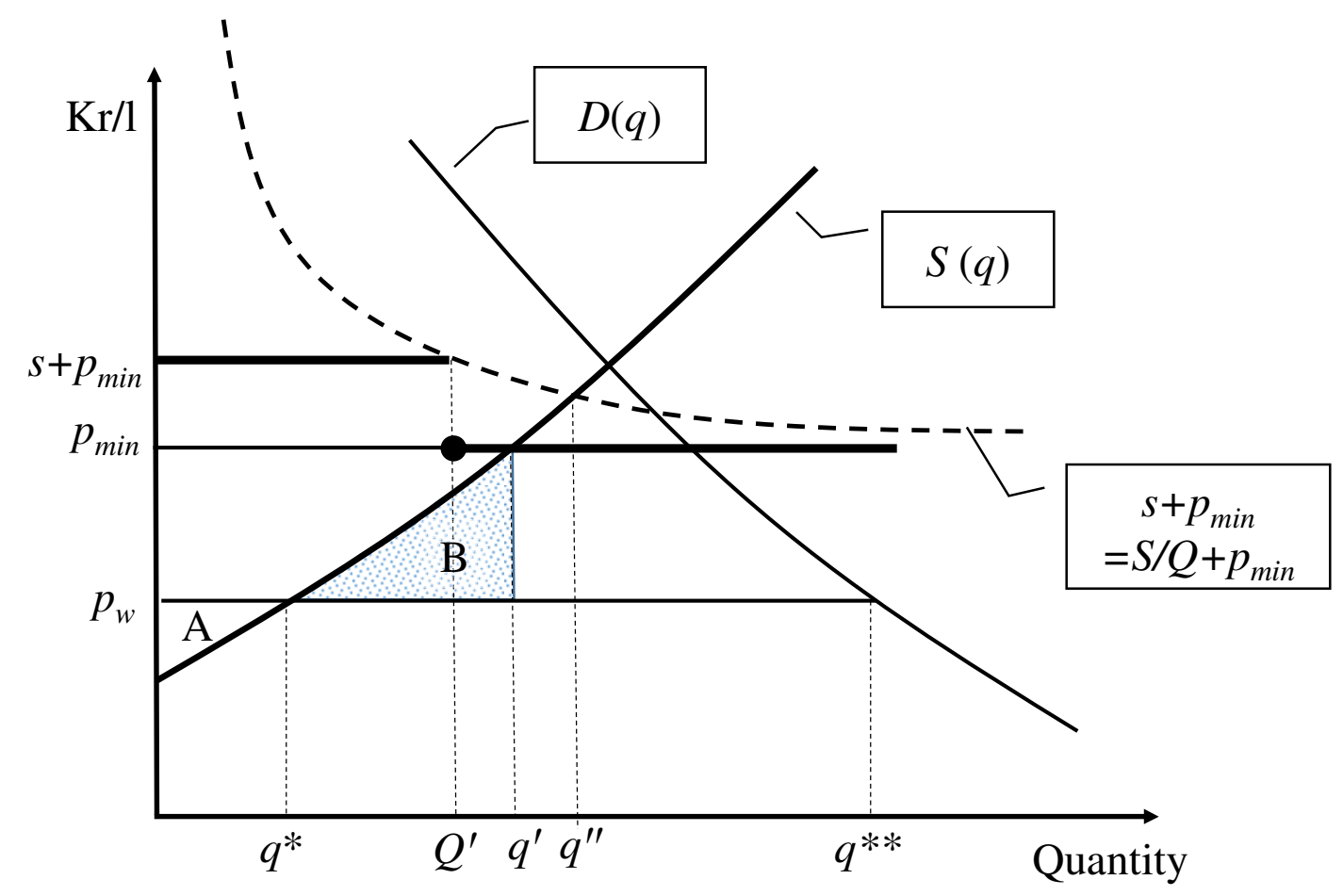

Figure 6. The domestic milk market: supports included

As the direct payment quota is set in the figure 6, i.e. at $Q^{\prime}$, dairy farmers find it profitable to produce in excess of this quota, more precisely at $q^{\prime}$. This is, as explained in section 2.3 above, in accordance with what has actually been the case under the direct payment system, as mentioned above.

Now, the production level $q$ is higher than the socially optimal production $q^{*}$. Therefore, as established by the social loss function, $L\left(q, q^{*}\right), q^{\prime}$ represents excessive production. More precisely, at $q$ ', there is a loss in social surplus approximately equal to the shaded area B in figure 6 .

From the perspective of this paper, however, the crucial point is that the inefficiency of producing at $q^{\prime}$ is entirely caused by the minimum price. The direct payments have nothing to do with it. It is easily seen from the diagram in figure 6 that dairy farmers would produce exactly the same volume of milk, i.e. $q$ ', even if there were no direct payments. In other words, the direct payments are in this case pure transfers. They do not affect the quantity of milk produced. All the production inefficiency of the dairy support system is solely generated by the minimum price

This finding, however, does not apply generally. It is entirely dependent upon the direct payment quota, $Q$, not being set too high. Thus, it is easy to see from figure 6 that if the direct payment quota is increased from $Q^{\prime}$ (for a fixed amount of direct payments, $S$ ), the level of production will ultimately start to rise. More precisely, this will happen when the direct payment quota, $Q$, exceeds $q$ '.

empirically relevant as the industry has consistently produced in excess of $Q^{\prime}$ (see section 2.3). Moreover, as will be explained below a sensible operation of the direct payments system requires that to be the case. 
Now, $q$ ' is the milk production dairy farmers would choose as a result of the minimum price but without any direct payments. This suggests the following result:

\section{Result 2}

The system of direct payments to dairy farmers will not lead to added production inefficiency compared to the system of minimum price provided the direct payment quota, $Q$, is not set above the level the farmers would select with only the minimum price and no direct payments.

So, it appears that if the authorities managing the dairy support system avoid setting the direct payment quota above the level, farmers would otherwise select, the system of direct payments will not generate production inefficiency in addition to that already created by the minimum price.

\subsection{The relationship between the direct payment quota and production inefficiency}

The above has established that whether the system of direct payments leads to increased milk production and, therefore, added production inefficiency depends on the size of the direct payment quota, $Q$. It therefore appears useful to investigate the relationship between the direct payment quota and the level of production further. To this we now turn:

Let us assume that the amount of direct payments, $S$, has already been decided. Let $q^{\circ}$ denote the profit maximizing production by dairy farmers. Then, the decision on the direct payment quota can lead to three distinct situations or phases:
I. $Q<q^{\circ}$,
II. $Q=q^{\circ}$,
III. $Q>q^{\circ}$.

It is important to realize that phase II applies to not merely one value of $Q$ but to a range defined by the interval $\left[Q_{\text {lower }}, Q_{u p p e r}\right]$. To see that this interval is of positive length it is sufficient to imagine $Q^{\prime}$ in figure 6 increasing to $q^{\prime}$ (which equals $Q_{\text {lower }}$ ) and from there to $q^{\prime \prime}$ (which equals $Q_{\text {upper }}$ ).

\section{Phase I. $Q<q^{\circ}$}

In this phase, the effective demand price to producers is $p_{\text {min. }}$ So the farmers' profit maximizing production level is simply determined by $S\left(q^{\circ}\right)=p_{\text {min. }}$. So, the profit maximizing production level, $q^{\circ}$, is independent of $Q$ as asserted in result 2 .

As already stated, this phase ends when the direct payment quota has reached $q^{\circ}$ defined above as $Q_{\text {lower. }}$. It may be helpful to recall that in figure $6, q^{\prime}=Q_{l o w e r} \equiv q^{\circ}$.

\section{Phase II. $Q=q^{\circ}$}

In this phase, the profit maximizing production level is simply $q^{\circ}=Q$. So the production level, and, therefore, the production inefficiency increases proportionately with the total direct payment quota, $Q$, reaching a maximum at $Q_{u p p e r}$ defined by $S\left(q^{\circ}\right)=p_{\min }+S / Q_{u p p e r}$. 


\section{Phase III. $Q>q^{\circ}$}

In this phase, the direct payment quota exceeds the actual milk production. The marginal revenues to milk producers, therefore, are given by $p_{\min }+S / Q$, where $S / Q$, as before, is the payment per litre. ${ }^{33}$ The quantity produced, therefore, is defined by $S\left(q^{\circ}\right)=p_{\min }+S / Q$. From this it is easy to see that the farmers' profit maximizing production level, $q^{\circ}$ falls with the level of the direct payment quota, $Q .{ }^{34}$ Moreover, while starting at the maximum defined by $S\left(q^{\circ}\right)=p_{\min }+S / Q_{\text {upper, }}$ it converges asymptotically to $S\left(q^{\circ}\right)=p_{\min }$ as the direct payment quota goes to infinity.

The overall relationship between the total direct payment quota and the actual production is summarized in figure 7. As illustrated in the figure, for any level of direct supports, $S$, provided the total direct payment quota, $Q$, is set below $Q_{\text {lower, }}$ the direct payments have no effect on the volume of milk production. The production remains as if there were no direct payments.

However, when the direct payment quota exceeds, $Q_{\text {lower, }}$ phase II is entered and milk production starts to increase proportionately with the direct payment quota reaching a maximum at $Q_{\text {upper }}$ defined by $Q_{\text {upper }}=S^{-1}\left(p_{\min }+S / Q_{\text {upper }}\right) .35$ Of course, with the direct payment quotas at $Q_{\text {upper, }}$ the production distortion of the support system is maximized with degree of social loss equalling $L\left(Q_{u p p e r}, q^{*}\right)=B\left(q^{*}\right)-B\left(Q_{\text {upper }}\right)$.

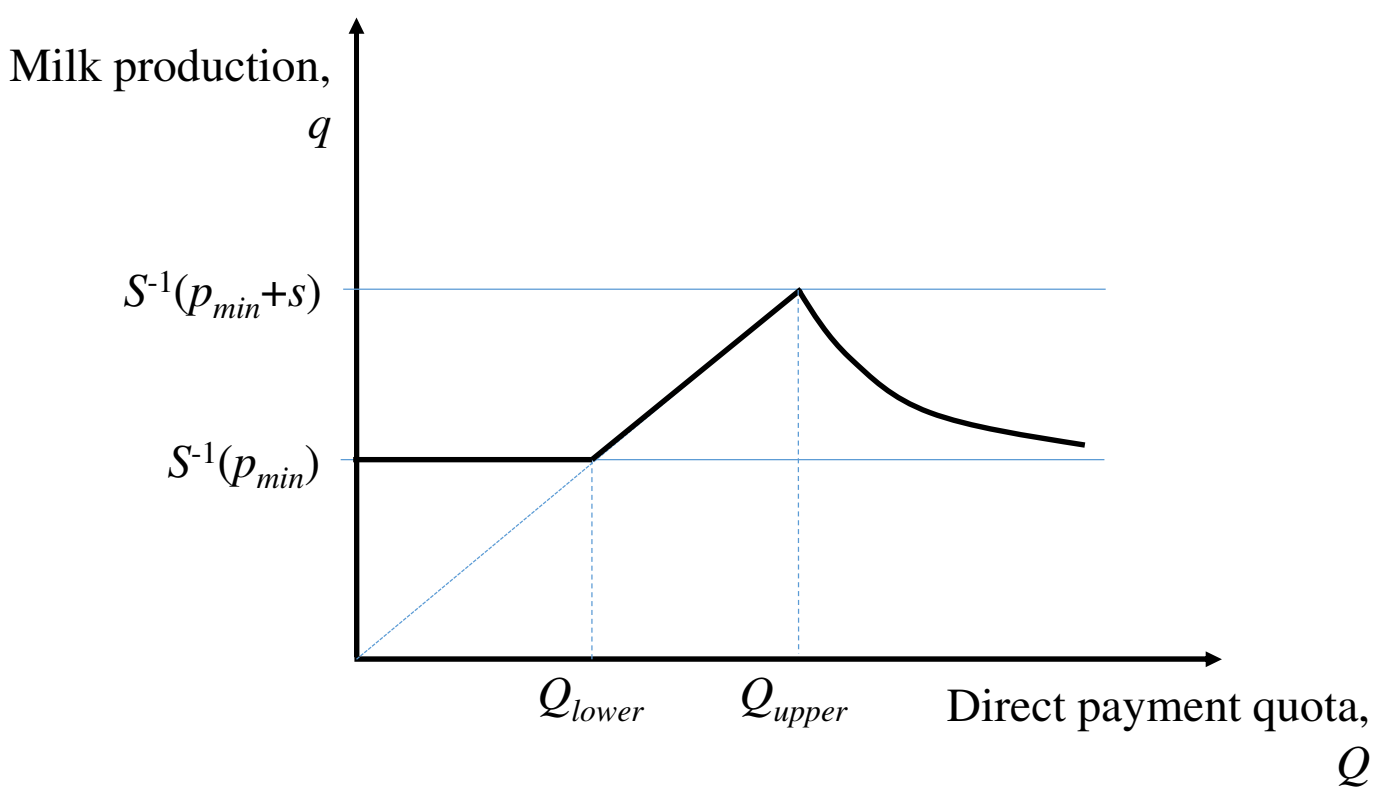

Figure 7. The impact of direct payment quota on milk production

$\left(S^{-1}(\right.$.$) on the vertical axis represents the inverse of the supply function). The domestic milk market: Supports included$

33 This assumes for simplicity that the payment conditions (see appendix A) are met so the direct payment price remains $s=S / Q$

34 To see this note that the derivative $\frac{\partial q^{\circ}}{\partial Q}=-\frac{S}{Q^{2}} \cdot \frac{1}{S_{q}}<0$.

35 Notice that $S^{-1}$ is the inverse of the supply function. 
Increasing the direct payment quota further leads to less production because the direct payments per litre fall with direct payment quota according to $s=S / Q$ leading to less and less production ultimately converging to $Q_{\text {lower }}$ when $Q$ approaches infinity and the direct payment per litre, s, converges to zero.

Thus, somewhat curiously, the system of direct payments to dairy farmer has no distortionary impact on milk production when the direct payment quota is less than $Q_{\text {lower }}$ or, alternatively, infinitely high.

\subsection{Non-distortion of the direct payment system: The general result}

According to Result 2, the system of direct payments does not increase the production of milk provided the direct payment quota, $Q$, is not set above the production level the farmers would choose with only the minimum price support and no direct payments. Clearly, the minimum price system does not play any particular role in this context. What is of importance is the production level without the direct payments, irrespective of how this is brought about. This suggests the following generalization of Result 2.

\section{Result 3}

The system of direct payments to dairy farmers will not lead to added production inefficiency provided the direct payment quota, $Q$, is not set above what the farmers would otherwise produce.

It is interesting to note that this result does not depend on the amount of direct payments, $S$. This can be as high or low as the authorities want. The authorities only have to be careful not to set the direct payment quota too high. Thus, the system of direct payments offers an effective way to bring social supports to farmers (and other producers) without affecting their production.

In the dairy farming support system discussed in this paper, there are two potential distortions; the minimum price and the direct payments. Both encourage production. However, they interact in an interesting way. First the minimum price encourages production to a level above the socially optimal one, namely $q^{\prime}$ compared to $q^{*}$ in figure 6 . Second the direct payments encourage production but only up to the level of the direct payment quota. Beyond the direct payment quota, there are no direct payments and therefore no encouragement to produce more. Thus, if the direct payment quota is set below what the farmers would produce anyway, the direct payments will have no impact on the level of production. Thus, in a sense, the minimum price, which induces the farmers to produce up to a certain level ( $q$ ' in figure 6) nullifies the potentially distortionary impact of the direct payments, provided the direct payment quota is not set too high.

It should be mentioned that after having derived Results 2 and 3 we discovered that a similar result had been claimed by Alston and James in 2002. ${ }^{36}$

36 According to Alston and James (2002, p. 1699): "If a quota set equal to the competitive quantity were combined with a subsidy, transfers from taxpayers to producers could be made without any distortions in production or consumption because the quota would prevent supply response to the subsidy." 


\section{Policy implications}

The analysis in section 3 shows that the dairy farming support system creates distortions that result in production inefficiency. Too much milk is produced. However, the different components of the support system; (i) tariffs, (ii) the minimum price, (iii) the direct payments and (iv) various other supports, are not equally detrimental in this respect. In particular, the system of direct payments does not add to the production inefficiency resulting from the minimum price, provided the total direct payment quota is not set too high. Interestingly, in the past, the direct payment quota has not been set too high. Every year since the late 1990s, the actual production of milk has been above and usually substantially above the direct payment quota. Thus, as it has been implemented, the system of direct payments has essentially been pure transfers from the state to dairy farmers with little or no distortionary impact.

There is another important advantage with the system of direct payments compared to many other types of supports. The rights embodied in the individual direct payments quotas and their transferability creates an additional, and possibly quite powerful, incentive for less efficient operators to sell and more efficient operators to purchase the rights and thus speed up the evolution toward increased efficiency in the dairy production industry.

This suggests that from the perspective of efficiency, the barriers to direct payment quota trading that have been erected within the current direct payments system should be removed. Most importantly; (i) quota trades should be allowed at any time, (ii) trades of temporary quotas as well as permanent quota transfers should be allowed and (iii) quotas should be perfectly divisible so that any part of the quota may be transferred.

Since they are clearly distortionary, the other components of the dairy support system, i.e. the minimum price and the various other supports should be reduced in favour of the direct payments system. What this means is that the financial support to dairy farmers contained in these other supports should be transferred to the system of direct payments. In that case, the authorities managing the support system have to be careful not to set the direct payment quota too high. In particular, they should be aware that as the minimum price is reduced, the direct payment quota may have to be reduced accordingly.

As a part of the official review of the dairy support system, it has been suggested that the direct payment system in its current form is somehow detrimental and should be modified. One proposal was to retain direct payments but abolish the direct payments quota, thus spreading the direct payments equally over all the entire milk production.

The findings of this paper show that this would be extremely ill-advised. Instead of the direct payments system having no impact on the level of production, this would lead to increased production and, therefore, added economic inefficiency of milk production. The result is in effect an example of the problem of the commons; a race for subsidies.

That this is the case can be easily verified with the help of figure 6 . If the direct payment quota is abolished, the demand price facing farmers would be $p_{\min }+S / q$ illustrated by the dashed curve in figure 6. Obviously, with this demand, price farmers would choose to produce at $q$ " in figure 6. This is higher than what they would otherwise select, which is q'. Thus, excess production is increased with additional social loss as illustrated in figure 5. Perhaps more strikingly, the production at $q$ " is really a production at $Q_{u p p e r}$ in figure 7, which maximizes the economic inefficiency that can be generated with the direct payments system for any given payment, $S$. 


\section{Discussion}

The system of direct payments provides monetary support to dairy farmers. Moreover this support is directly related to their level of production up to a certain upper bound. Thus, it is clearly a production subsidy. A standard result in economic theory is that production subsidies generally lead to increased production. However, according to the analysis of this paer, this is not the case for the system of direct payments over a wide range of direct payment quotas.

What is happening here is that the dairy support system contains two distortionary incentives; the minimum price and the direct payments. Both encourage production. However, they interact in an interesting way. First the minimum price encourages production to a level above the socially optimal one. Second the direct payments encourage production but only up to the level of the direct payment quota. Beyond the direct payment quota, there are no direct payments and therefore no encouragement to produce more. Thus, if the direct payment quota is set below what the farmers would choose to produce anyway, the direct payments will have no impact on the level of production. Thus, in a sense, the minimum price, which induces the farmers to produce up to a certain level nullifies the potentially distortionary impact of the direct payments, provided the direct payment quota is not set above that level.

This may be taken to suggest that if the minimum price were abolished but the system of direct payments retained, the latter would lead to excessive production compared to the what is socially optimal. This interpretation, however, would be too simplistic.

The system of direct payments only distorts production if the direct payment quota is set above the level that farmers would choose without it. If the direct payment quota is set below that level, the system of direct payments will not distort production. Thus, with no minimum price, a system of direct payments will not generate excess production if the total payment quota, $Q$, is not set above the socially optimal production level ( $q^{*}$ in figure 6 and figure 4 ). 


\section{References}

Act No. 5/1992. Lagasafn. http://www.althingi.is

Act No. 112/1992. Lagasafn. http://www.althingi.is

Act No. 99/1993. Lagasafn. http://www.althingi.is

Act No. 102/2016. Lagasafn. http://www.althingi.is

Alston, J.M. and James, J.S. (2002). The incidence of agricultural policy. Handbook of Agricultural Economics, 2, 1689-1749.

Ásmundsdóttir, F. (2012). Framleiðslustýring í landbúnaði - áhrif á stærð og fjölda kúabúa (BS thesis). Háskóli Íslands.

Hagfræðistofnun. (2015). Mjólkurvöruframleiðsla á Íslandi - Staða og horfur. Reykjavik: Hagfræðistofnun Háskóla Íslands.

Hicks, J.R. (1946). Value and Capital. Claredon Press: Oxford.

Kristófersson, D.M., Bjarnadóttir E., and Jónsson, Ó.S. (2007). Eignarhald á jörðum, framleiðslu og próun hennar. Freyr, 103 (1), 29-33.

Landbúnaðarráðuneytið. (2004) Stöðumat og stefnumótun i mjólkurframleiðslu, skýrsla til landbúnarðarráðherra, febrúar 2004. Reykjavik: Ministry of agriculture.

Landssamband kúabænda. (2015). Stefnumörkun vegna samnings um starfsskilyrð̈i nautgriparæktarinnar. Skjal lagt fyrir fulltrúafund LK dagsett 24. nóv. 2015.

Rannís (2001). Staða og próunarhorfur í nautgriparækt á Íslandi. Reykjavík: Rannsóknarráð Íslands.

Ríkisreikningur 2016. http://wwww.fjs.is

SAM (2002-2016). Ársskýrslur. For calander years 2002-2016. Association of Dairies.

Stefánsson, B. (1986). Verðlagning Landbúnaðarafurða í 100 ár. Landshagir: Pættir úr íslenskri atvinnusögu. Reyjkavik: Landsbanki Íslands.

Stefánsson, G. (1998). Landbúnaðarstefnan og búvörusamningar. Ráðunautafundur 1998. Reykjavik: Rannsóknastofnun landbúnaðarins og Búnaðarfélag Íslands. 3-12.

Varian, H. (1984). Microeconomic Theory. Second edition. New York: W.W. Norton \& Company.

Willig, R. D. (1976). Consumer Surplus without Apology. American Economic Review 66(4), 589-97. 


\section{Appendix}

\section{The arrangement of the direct payments}

Under the direct payment system, the Ministry of Agriculture (now Ministry of Fisheries and Agriculture) each year issues regulations stipulating the total amount of direct payments, $S$, as well as the corresponding total volume of direct payment quota, $Q$, for the following year. ${ }^{37}$ $T h i s$ leads to the direct payments per litre of $s=S / Q$. However, the Ministry has over the years imposed various conditions on how the direct payments can actually be paid. These conditions may in principle modify the direct payments, $s$, actually received by farmers although they don't seem to have done so in the past.

As an example of how this works; Regulation no. 1220/2015 stipulated the total direct payments to be 5.5 billion $\mathrm{kr}$. in 2016 for a volume of 136 million litres of milk, which results in a calculated average direct payment price of $40.6 \mathrm{kr}$. pr. litre. ${ }^{38}$ The actual payments, which are made monthly, were however divided into three categories apparently to provide incentives for dairy farmers to produce the full amount of their quota (or as close to that mark as possible) and to do so evenly throughout the year. The payments (in 2016) were divided in the following categories:

- Category A: $40 \%$ of the total direct payments are paid regardless of the quantity produced by the producer in question, provided his production reaches at least $80 \%$ of the production quota of the farm. For less production, these $40 \%$ are paid proportionately per unit produced. Payment is made on the 1st day of the month in advance, per $1 / 12$ of the targeted production. ${ }^{39}$

- Category B: $35 \%$ of the total direct payments, paid per produced litre, up to a maximum of the production quota of the producer. Payment is made on the 1st day of the month for the production of the penultimate month. ${ }^{40}$

37 As mentioned in Section 1 and footnote 5, the amount of the payments are those stipulated in the agreement on dairy production between the government and the Farmer's Association. The Ministry then, after consulting with the association of dairy farmers and association of dairies, annually sets the total volume of milk that will receive direct payments during the following calendar year.

38 The regulations were issued on December 18, 2015 only a few days before coming into effect (on January 1, 2016). Although the formal decision therefore comes at little notice, farmers would have known what to expect, with high probability, some months earlier, as it is based on recommendations from the Association Milk Processors (SAM) and the National Association of Cow Farmers (Landssamband kúabænda) and the Agreement on Dairy Production. Nevertheless, this is a short notice, especially if there are large changes in the total volume (which translates into large volume changes for each farmer, as each farmer has a share in the total), which may require an increased number of milking cows to produce the increased quota.

39 The minimum production requirement of $80 \%$ in 2016 has varied in previous years, $100 \%$ in 2015 , $95 \%$ in $2014,90 \%$ in $2004-2013$, and $85 \%$ in the immideate years preceding that.

40 Unused direct payments are then distributed further in accordance with Categories A and B, to eligible producers (see Regulation no. 120/2015, articles 3 and 5). Dairy farmers that have produced in excess of their quota can therefore receive this additional support. This unused portion of the support payments can amount to 2-3\% of milk in excess of the quota of the eligible producers. 
- Category C: $25 \%$ of the total payments, paid per production (not exceeding the total payment quota of each farm) in selected months to ensure sufficient supply the whole year round (June through December were the specified months).

This division of the support payments into categories may seem to suggest that the typical farmer is facing different marginal and average prices throughout the year and that this could (and should) affect his decision on production. Looking at the 2016 support price and its division, Category A price is 16.24 kr. pr. litre, Category B is 14.21, and Category C is 18.27 in June-November and 12.18 in December (the calculations here for June-Dec. assume that 1/12 of the total payment quota volume is weiged in to a dairy in each of those months). This then results in a (total) support price per litre of 30.45 in Jan.-May, 48.72 in June-Nov., and 42.63 in Dec. compared to the average annual support price of 40.60 per litre. However, calculating the marginal prices (let alone the average prices) is even more complicated than this, as these prices only apply conditional on a given volume of production (weighed in) in certain months (1/12 of the total payment quota in each of the months June-Dec.). Dairy farmers whose production depends very much on the number of milking cows they have invested in will find it difficult to vary their production to these rather complex prices. There is also an annual production cycle, due to calving and feed quality variations. For these reasons, production each year is well above average in the months of Mars-June, above average in January and July, on average in December, but below average in February and August, and well below average in September-November. This, in effect, results in production well above quota for the typical farmer in the above-average months and in production in the below-average months being close to his quota. ${ }^{41}$ There is seemingly little flexibility in the short-run to adjust production to changing marginal prices. Therefore, it appears that the farmers' profit maximizing strategy is to produce at least their direct payments quota so long as the marginal price for the year (direct payment $40.6 \mathrm{kr}$. plus the minimum price of 85.3 in 2016) is higher than their marginal cost of producing. If it isn't, the farmer would be better off selling his quota.

Profit maximizing farmers will therefore apply the marginal rule; produce a volume where the marginal revenue (the price at the margin here) equals marginal cost. A farmer operating within the Icelandic dairy support system in 1992-2016 will look at the total unit price at the margin, which consists of the price that the dairy processor pays combined with the government support price. For the profit maximzing farmer that is the relevant marginal price. ${ }^{42}$ In 2016 this price was $125.9 \mathrm{kr}$. per litre in total for all milk a farmer produced within

41 In fact, the farmers as a group fail every year in producing their full quota volume in some of the Autumn months. That is, in each of the past 6 years the farmers come up short of producing the 1/12 of the yearly total payment quota volume in the months of Sept.-Nov. They have missed this by anywhere from 0.1 million litres and up to 0.9 million litres (see Ársskýrsla SAM for the years 20022016, see http://sam.is/um-sam/arsskyrslur-sam/). If in-weighed milk (within quota) is less than 1/12 of the total payment quota, this results in a higher Category $\mathrm{C}$ price per litre. And when in-wighed milk (within quota) is more than 1/12 of the total payment quota, that results in a lower Category $\mathrm{C}$ price per litre. The Category $\mathrm{C}$ price per litre that a particular farmer receives therefore depends not only on his production in a given month but also on the amount the other farmers weigh in during the same month.

42 One should not be tempted to think that the farmer will attempt to maximize the average price or marginal price, which would occur at a production level below $100 \%$ of his quota if the minimum required production is below $100 \%$. Maximum average or marginal price will not lead to maximum profits; producing up to the quantity where marginal revenue equals marginal costs will. 
his quota; 40.6 in direct payments and 85.3 the minimum guaranteed price from the processor. But the price was only $85.3 \mathrm{kr}$. per litre for any milk in excess of the quota (and, in fact, only $65.3 \mathrm{kr}$. after July 1, 2016). ${ }^{43}$ The typical farmer will therefore first look at the margin of producing his full quota and the relevant price there is the total sum of the minimum and direct payments price. The actual production volume in recent years (since at least 2005) suggests that the total sum of these prices was well above marginal cost at the full direct payments quota level, at least for most farmers. Moreover, it appears that the minimum guaranteed price has also been above the marginal cost, at least for many farmers, as can be seen in that the industry has produced well beyond the direct payments quota since 2005 (see table 2). Under such conditions, the direct payments from the government do not affect the farmers' production volume: These payments are intra-marginal and therefore have a similar effect as lump sum transfers; no effect on the volume margin. ${ }^{44}$

Qver the years there has been much variability in the conditions for actually receiving all components of the direct payments and this is an additional reason for not trying to model them. Moreover, since the conditions have in in general been met by the farmers as a whole, using the direct payment price of $s=S / Q$ seems sufficiently accurate in practice.

43 Auðhumla, which is a cooperative which most milk farmers belong to, and owner of the largest milk processing company, announced on April 1, 2016, that the effective price for excess milk would be lowered by $20 \mathrm{kr}$. from July 1, 2016. The reason given was too much excess production and anticipation that farmers planned even more production. This was the first time since September 2013 that the price for excess milk was lower than the minimum guaranteed price. This lowering of the price seemingly had the effect that production from July onwards fell by an average of 2.8 per month compared to the same months in 2015 (Ársskýrsla SAM 2016 see http://sam.is/pages/1forsiduvefgreinin-um-sam/arsskyrslur-sam/arsskyrsla-sam-2016/).

44 This seems to apply to the typical farmer and probably almost all farmers, the possible exception being some small farmers (those with fewest cows) who may not be able to adjust quickly to large changes in regulations that are announced with short notice (the available information in the annual reports of SAM suggests that usually less than $1 \%$ of individual farmers' total direct payments quotas are left unused. See http://sam.is/um-sam/arsskyrslur-sam/). This exception regarding small farmers became apparent in 2015 when the production requirement for Category A payments was increased to $100 \%$ at the same time the total direct payments quota was increased by $12 \%$ (on top of nearly $8 \%$ increase the preceding year). Some number of smaller farmers had problems producing their full quota that year. The regulations inadvertently met this problem by lowering the share of Category A payments from $47.67 \%$ in 2014 to $40 \%$ in 2015. Inadvertently as this change in the share of Category A payments was really intended to provide more incentive to increase production in specified months of the year, the share for Category C payments increased from $16.88 \%$ in 2014 to $25 \%$ in 2015 and June was added to July-Dec. 